\title{
Ageing Perception as a Key Predictor of Self-Rated Health by Rural Older People-A Study with Gender and Inclusive Perspectives
}

\author{
Vanessa Zorrilla-Muñoz ${ }^{1,2, * \mathbb{D}}$, María Silveria Agulló-Tomás ${ }^{1,3} \mathbb{( D}$, Carmen Rodríguez-Blázquez ${ }^{4}$, Alba Ayala ${ }^{5}$, \\ Gloria Fernandez-Mayoralas ${ }^{6}$ and Maria João Forjaz ${ }^{7}$ (D)
}

check for

updates

Citation: Zorrilla-Muñoz, V.;

Agulló-Tomás, M.S.;

Rodríguez-Blázquez, C.; Ayala, A.; Fernandez-Mayoralas, G.; Forjaz, M.J. Ageing Perception as a Key Predictor of Self-Rated Health by Rural Older People-A Study with Gender and Inclusive Perspectives. Land 2022, 11, 323. https://doi.org/10.3390/ land11030323

Academic Editor: Claudia A. Radel

Received: 31 December 2021

Accepted: 14 February 2022

Published: 23 February 2022

Publisher's Note: MDPI stays neutral with regard to jurisdictional claims in published maps and institutional affiliations.

Copyright: (c) 2022 by the authors Licensee MDPI, Basel, Switzerland. This article is an open access article distributed under the terms and conditions of the Creative Commons Attribution (CC BY) license (https:// creativecommons.org/licenses/by/ $4.0 /)$.
1 University Institute on Gender Studies, University Carlos III of Madrid, Getafe, 28903 Madrid, Spain; msat@polsoc.uc3m.es

2 Department of Mechanical Engineering, University Carlos III of Madrid, Leganes, 28911 Madrid, Spain

3 Department of Social Analysis, University Carlos III of Madrid, Getafe, 28903 Madrid, Spain

4 National Center of Epidemiology and CIBERNED, Institute of Health Carlos III and CIBERNED, 28029 Madrid, Spain; crodb@isciii.es

5 Department of Statistics, University Carlos III of Madrid, Getafe, 28903 Madrid, Spain; aayala@est-econ.uc3m.es

6 Institute of Economics, Geography and Demography (IEGD), Centre for Human and Social Sciences (CCHS), Spanish National Research Council (CSIC), 28037 Madrid, Spain; gloria.fernandezmayoralas@cchs.csic.es

7 National School of Public Health, Institute of Health Carlos III and REDISSEC, 28029 Madrid, Spain; jforjaz@isciii.es

* Correspondence: vzorrill@ing.uc3m.es

\begin{abstract}
This paper investigates positive perceptions of ageing in rural people aged 65 and over as a key predictor of the self-assessment of one's health. Method: The sample covers a total of 3389 people from the 'Survey of Health, Ageing and Retirement' (SHARE), wave 6 (W6, 2015). This research analyses men and women who live in a rural environment. A linear regression model is proposed to consider the dependent variable 'self-rated health' and independent variables based on measures of quality of life in older adults. This study confirms that rural women perceive their health on the basis of factors different to those of their male contemporaries. The variable 'How often do you feel/think that you can do the things that you want to do?' is associated with women's self-perceived health. In men, a high relationship (with $p<0.001$ ) is obtained for the variables 'How often do you feel/think look back on your life with a sense of happiness?' and 'How often do you feel/think that family responsibilities prevent you from doing what you want to do?' Certain daily activities (e.g., leisure or care), along with a positive perception of life, influence one's perceptions of one's own health, especially in the case of women. In sum, rural older women make a positive evaluation of their own health and ageing, while rural older men relate self-rated health to passivity and reminiscing. There is a need for further research on psycho-social and socio-spatial issues from an intergenerational, technological and gender perspective for rural and territorial influences to attain better health and quality of life for rural older people in comparison to urban people.
\end{abstract}

Keywords: rural; self-perceived health; older people; gender; activity; socio-spatial

\section{Introduction}

The age of the world population has increased in recent decades. According to data from the World Bank (2020), 9.321\% of the total global population are aged 65 years and above, which indicates an increase of $3.069 \%$ since the year 1990 [1]. Global projections have estimated an increase in life expectancy for 2050, when two-thirds of the population in low- and middle-income countries will be over 60 [2]. Moreover, the current pandemic has highlighted the need to consider challenges in policies and actions to face demographic change in order to maintain well-being, quality of life and active ageing. Within all this, the 
World Health Organization (WHO) is leading an international commitment to improve the lives of older people, their families and communities by declaring 'The Decade of Healthy Ageing', stating: 'A decade of concerted global action on healthy ageing is urgently needed to ensure that older people can fulfil their potential in dignity and equality and in a healthy environment'. The action areas are centred on four themes: (1) 'Age-friendly environments' and better places to promote non-discriminatory opportunities free of physical and social barriers; (2) 'Combating Ageism', an effort to reduce and eliminate negative behaviours, perceptions, prejudices and stigma that have negative effects on the well-being and health of older people; (3) 'Integrated care', with non-discriminatory access to health services; (4) 'Long-term care', which addresses issues relating to more accessible resources, support, spaces and technologies to contribute to improving the situations of dependency and disability, providing dignity to people living in these situations [3].

Given that healthy old age is linked to well-being during the ageing process, sociogerontological studies have shown that certain activities of daily life (such as leisure and voluntary activities, among others), along with a favourable perception of life itself, have a positive influence on quality of life ([4-6], among others). In addition, classic authors (for example, Havighurst [7], Spreitzer and Snyder [8] and Brandtst [9], among others) defend the thesis that activity is central to enjoying a higher quality of life as we become older. The idea that active ageing improves quality of life is also commented on in the WHO's own definition quality of life in the 'World Health Organization Quality of Life Questionnaire' (WHOQOL) in 1994 [10] and, more intensely, from 2000 [11,12] to the present day [13-15]. Moreover, there are gender differences in the leisure activities and voluntary work performed by older people; i.e., older women are caregivers regardless of if they live in rural or urban areas. Moreover, these older caregivers demand more programmes based on family needs assessment and family careers [16,17]. In particular, some examples of programmes demanded by rural women who care for older people are leisure programmes independent of the living environment $[16,18]$ and programmes for reducing loneliness and isolation in rural environments [19]. The improvement of quality of life also addresses aspects that enrich the terms of active or successful ageing, such as health and well-being, among others $[11,20]$. From this perspective, some resources, such as the WHOQOL (https://www.who.int/healthinfo/survey/whoqol-qualityoflife/en/, accessed on 20 November 2021) (see, for example, von Steinbüchel [21,22], among others), have been used to assess quality of life in this population and demonstrate differences between women and men in ageing. All of these differences show that quality of life is also associated with health-related indicators, as other authors have previously considered [23,24]. From another perspective, the concept of 'ikigai' is an oriental term that refers to the vital meaning of and attitudes about life (see commentaries related to "ikigai" in blogs, such as: https: / / qaspresearch.wixsite.com/blog/post/ikigai-activity-and-older-european-women, accessed on 20 November 2021), perceived health and other aspects that can be viewed differently by older women and men. Moreover, 'ikigai' is outstanding in the case of living in rural communities [25].

The improvement of quality of life and health determinants has brought success to ageing and the consequent increase in life expectancy. Additionally, the success of ageing entails the need to achieve important challenges in relation to welfare policies, economies and society in countries with high life expectancy, e.g., European countries, including Spain, which is expected to have the world's highest life expectancy in 2040 [26]. The phenomenon of increased life expectancy relates more to women because their quality of life is better, which does not mean that women age better in the sense of having better health.

Some authors, such as Wenger [27], among others, have noted that rural ageing has received less attention than urban ageing in aspects regarding rural lifestyles, the importance of community networks and family support, life satisfaction and access to care services, among others. However, the few studies conducted indicate that rural living, or ageing in rural areas, creates a positive vision of cognitive health and social support [28], behaviour that promotes health and satisfaction with life in rural older 
women living alone [29] and social support factors associated with self-rated health, such as intergenerational social contact [30]. One negative aspect is the difficulty of accessing primary health services, especially for populations with disabilities [31], which include older people in situations of dependency.

Health is undoubtedly an indicator of quality of life in older people. It can be perceived through variables related to functional capacity, psychological well-being and mental health, but also others related to personal experiences during the ageing process [32], especially when there is a related positive perception of ageing [33]. The perception of ageing is an area of interest in ageing population surveys conducted to acquire important data about health and social variables. Questionnaires about perceptions of ageing make it possible to analyse the emotional representation of the perceptions of ageing [34]. Self-perception of ageing is a factor which affects the success of ageing [35,36]. Furthermore, the selfperception of ageing is a factor which allows us to understand death anxiety [37] and frailty [38] and predict the persistence of depression and anxiety [39] among older people. However, few studies have analysed the perception of ageing as it relates to older adults' health (see, for example, the study of Warmoth et al. [40], Hickey et al. [41] or Sadegh Mohhamad [42]). Several resources for gathering perception about ageing have been validated, for example, the Brief Ageing Perceptions Questionnaire (B-APQ) [34], the Dutch Aging Perceptions Questionnaire [43] and the Brief Ageing Perception Questionnaire in Malaysia [44]. However, there is no resource linked to ageing perception as a key predictor of self-rated health by rural older people. Moreover, positive perceptions of ageing and self-rated health among rural older people are still scarce. It is hypothesized that rural older women have a different perception of health compared with their male contemporaries. For these reasons, the objective of this study is to determine which self-perceived ageing variables are related to the perception of self-rated health in rural older people in Spain. The analysis is conducted on the basis of differences by sex.

\section{Materials and Methods}

This study utilises data from the Survey of Health, Ageing and Retirement (SHARE: http://www.share-project.org/home0.html, accessed on 15 November 2021), wave 6 (W6, 2015) [45]. Wave 6 contains the latest updated variables regarding perceptions of ageing in older people. Access to the questionnaire data is free for the purpose of scientific use. SHARE data are protected by factual anonymity (as defined by the strict norms of the German Federal Statistics Act and the German Federal Data Protection Law) [46]. The collection of the data is anonymously recorded. The use of the data is subject to the European Union General Data Protection Regulation (GDPR), 'Regulation (EU) 2016/679 of 27 April 2016 on the protection of natural persons related to the processing of personal data and on the free movement of such data, and repealing Directive 95/46/EC'. The SHARE data collection procedures are subject to continuous ethics review. SHARE-ERIC's activities related to human subject research are guided by international research ethics principles, such as the Respect Code of Practice for Socio Economic Research (http:/ / www.share-project.org/fileadmin/pdf_documentation/respect_code_ socio_economic_research.pdf, accessed on 10 January 2022) (professional and ethical guidelines for the conduct of socio-economic research) and the Declaration of Helsinki (http: / / www.share-project.org/fileadmin/pdf_documentation/Declaration_of_Helsinki.pdf, accessed on 10 January 2022) (a set of ethical principles regarding human experimentation developed for the medical community by the World Medical Association, last revised at the 64th WMA Meeting held in Fortaleza, Brazil in October 2013). As SHARE users, we were familiar with the fundamental principles of research ethics (e.g., see guidelines mentioned above) and we take them into account in an appropriate manner when conducting research using SHARE data [46]. 


\subsection{Participants}

The participants of this study were recruited voluntarily. Our sampling strategy is defined in the paper by Bergmann et al. [47]. The geographically dispersed sample consisted of rural Spanish people aged $\geq 65$ years, the majority of whom were living in rural areas $(n=3389)$ and were recruited for the W6 SHARE project [48]. Women represented 53.8\% of the sample $(n=1826)$, and $60.4 \%$ of the participants were limited in activities as a result of mobility difficulties or chronic diseases. In relation to tobacco use, which can aggravate chronic diseases, e.g., diabetes (see [49], among others) or cardiovascular diseases (see [50], among others), $43.81 \%$ of the sample reported smoking daily. The mean body mass was $27.41(\mathrm{SE}=0.057)$. As for drugs related to COVID-19 risk diseases, $20.09 \%$ were taking drugs for diabetes, $13.45 \%$ for coronary diseases and $3.95 \%$ for chronic bronchitis. The regression analysis was gender-stratified.

\subsection{Data Analysis}

The variables were selected to represent self-rated health and measure quality of life in older aged people. Quality of life is divided in four main subscales: control, autonomy, pleasure and self-realization. The measure for quality of life used the CASP-12 scale [51-53], to which we added the self-realization variable 'How often do you feel satisfied with activities (volunteering, hobbies etc ... ) ?' The dependent variable was the perceived health status. The dependent and independent variables used a Likert-type scale from 1 to 4 (where 1 signifies 'not at all' and 4 is 'a lot'), except in the variable 'How often do you feel satisfied with activities (volunteering, hobbies etc ... )?', in which case a 1-to-10 scale was used ( 1 being 'not at all' and 10 being 'a lot'). As all of these variables were single Likert-type scale variables, stringent levels were considered in the first calculation (https:/ / www.theanalysisfactor.com/can-likert-scale-data-ever-be-continuous/, accessed on 10 January 2022): Spearman's test, the Kaiser-Meyer-Olkin (KMO) test and a uniqueness criterion not stratified by gender. This analysis provides an idea of the ageing perception and self-rated health with Likert-type scale variables. Spearman's test was performed with age-related perception variables and self-rated health. The selected variables covered the following requirements: Spearman's test for two $p$-value probability levels, $p<0.005$ and $p<0.001$ (both very strong evidence for rejecting $\mathrm{H} 0$ ), and a uniqueness criterion for values $\geq 0.4$ with optimal criteria for $\geq 0.6$ and $\mathrm{KMO}(0<\mathrm{KMO}<1)$. Second, all predictors were entered into the two linear regression models, simultaneously stratifying by gender.

\section{Results}

Table 1 shows the mean and standard deviation of the dependent variable 'Selfperceived health' and the 13 selected independent variables. The variables relating to ageing perception have a positive trend for both sexes in the case of 'How often do you feel that life is full of opportunities?', 'How often do you feel/think that the future looks good for you?' and 'How often do you feel/think satisfied with activities?' Some of the negative variables are 'How often do you feel/think that family responsibilities prevent you from doing what you want to do?', 'How often do you feel/think that what happens to you is out of your control?', 'How often do you feel/think left out of things?' and 'How often do you feel/think that shortage of money stops you from doing the things you want to do?', among others. 
Table 1. Variables selected from the SHARE questionnaire: mean and standard deviation.

\begin{tabular}{|c|c|c|c|c|}
\hline Subscale & Variables & $\begin{array}{c}\text { Total }(N=3389) \\
\quad(\text { Mean } \pm \text { SE) }\end{array}$ & $\begin{array}{c}\text { Men }(N=1563) \\
(\text { Mean } \pm S E)\end{array}$ & $\begin{array}{c}\text { Women } \\
(N=1826) \\
(\text { Mean } \pm \text { SE) }\end{array}$ \\
\hline Self-rated health & Self-perceived health & $3.31 \pm 0.02$ & $3.21 \pm 0.03$ & $3.41 \pm 0.03$ \\
\hline Control & $\begin{array}{l}\text { How often do you think your age prevents you } \\
\text { from doing the things you would like to do? }\end{array}$ & $2.44 \pm 0.03$ & $2.49 \pm 0.04$ & $2.38 \pm 0.04$ \\
\hline Control & $\begin{array}{l}\text { How often do you feel that what happens to you } \\
\text { is out of your control? }\end{array}$ & $3.01 \pm 0.02$ & $3.10 \pm 0.03$ & $2.92 \pm 0.04$ \\
\hline Control & How often do you feel left out of things? & $3.40 \pm 0.02$ & $3.44 \pm 0.03$ & $3.37 \pm 0.03$ \\
\hline
\end{tabular}

Table 1. Cont.

\begin{tabular}{|c|c|c|c|c|}
\hline Subscale & Variables & $\begin{array}{c}\text { Total }(N=3389) \\
(\text { Mean } \pm \text { SE })\end{array}$ & $\begin{array}{c}\text { Men }(N=1563) \\
(\text { Mean } \pm \text { SE) }\end{array}$ & $\begin{array}{c}\text { Women } \\
(N=1826) \\
(\text { Mean } \pm \text { SE) }\end{array}$ \\
\hline Autonomy & $\begin{array}{l}\text { How often do you think that you can do the } \\
\text { things that you want to do? }\end{array}$ & $2.04 \pm 0.02$ & $1.99 \pm 0.03$ & $2.08 \pm 0.03$ \\
\hline Autonomy & $\begin{array}{l}\text { How often do you think that family } \\
\text { responsibilities prevent you from doing what you } \\
\text { want to do? }\end{array}$ & $3.21 \pm 0.02$ & $3.22 \pm 0.03$ & $3.20 \pm 0.03$ \\
\hline Autonomy & $\begin{array}{l}\text { How often do you think that shortage of money } \\
\text { stops you from doing the things you want to do? }\end{array}$ & $2.59 \pm 0.03$ & $2.57 \pm 0.04$ & $2.61 \pm 0.04$ \\
\hline Pleasure & How often do you look forward to each day? & $1.63 \pm 0.02$ & $1.60 \pm 0.03$ & $1.67 \pm 0.03$ \\
\hline Pleasure & $\begin{array}{l}\text { How often do you feel that your life has } \\
\text { meaning? }\end{array}$ & $1.54 \pm 0.02$ & $1.48 \pm 0.02$ & $1.60 \pm 0.03$ \\
\hline Pleasure & $\begin{array}{l}\text { How often, on balance, do you look back on your } \\
\text { life with a sense of happiness? }\end{array}$ & $1.72 \pm 0.02$ & $1.66 \pm 0.03$ & $1.78 \pm 0.03$ \\
\hline Self-realization & How often do you feel full of energy these days? & $2.02 \pm 0.02$ & $1.91 \pm 0.03$ & $2.14 \pm 0.03$ \\
\hline Self-realization & $\begin{array}{c}\text { How often do you feel that life is full of } \\
\text { opportunities? }\end{array}$ & $2.15 \pm 0.02$ & $2.09 \pm 0.03$ & $2.21 \pm 0.03$ \\
\hline Self-realization & $\begin{array}{l}\text { How often do you feel that the future looks good } \\
\text { for you? }\end{array}$ & $2.21 \pm 0.02$ & $2.13 \pm 0.03$ & $2.28 \pm 0.03$ \\
\hline Self-realization & $\begin{array}{l}\text { How often do you feel satisfied with activities } \\
\text { (volunteering, hobbies etc ... ) ? }\end{array}$ & $8.09 \pm 0.04$ & $8.08 \pm 0.05$ & $8.10 \pm 0.06$ \\
\hline
\end{tabular}

Table 2 shows the results of the SHARE questionnaire. We observed a Spearman's coefficient in all variables with a moderate range of -0.40 to 0.48 . Uniqueness results between 0.41 and 0.84 were obtained. The total KMO obtained was 0.87 . 
Table 2. Variables selected from the SHARE questionnaire and statistical analysis: Spearman, KMO and uniqueness.

\begin{tabular}{|c|c|c|c|}
\hline $\begin{array}{c}\text { Variables } \\
\text { How Often Do You Feel/Think ... ? }\end{array}$ & Spearman & KMO & Uniqueness \\
\hline $\begin{array}{c}\text { How often do you think your age prevents you from } \\
\text { doing the things you would like to do? }\end{array}$ & $-0.40^{* * *}$ & 0.87 & 0.57 \\
\hline $\begin{array}{l}\text { How often do you feel that what happens to you is out of } \\
\text { your control? }\end{array}$ & $-0.31^{* * *}$ & 0.83 & 0.47 \\
\hline How often do you feel left out of things? & $-0.22 * * *$ & 0.84 & 0.57 \\
\hline $\begin{array}{l}\text { How often do you think that you can do the things that } \\
\text { you want to do? }\end{array}$ & $0.27^{* * *}$ & 0.93 & 0.81 \\
\hline $\begin{array}{l}\text { How often do you think that family responsibilities } \\
\text { prevent you from doing what you want to do? }\end{array}$ & -0.01 & 0.70 & 0.79 \\
\hline $\begin{array}{l}\text { How often do you think that shortage of money stops you } \\
\text { from doing the things you want to do? }\end{array}$ & $-0.16^{* * *}$ & 0.80 & 0.80 \\
\hline How often do you look forward to each day? & $0.33^{* * *}$ & 0.84 & 0.41 \\
\hline How often do you feel that your life has meaning? & $0.31^{* * *}$ & 0.84 & 0.41 \\
\hline $\begin{array}{c}\text { How often, on balance, do you look back on your life with } \\
\text { a sense } \\
\text { of happiness? }\end{array}$ & $0.09 * * *$ & 0.89 & 0.78 \\
\hline How often do you feel full of energy these days? & $0.48^{* * *}$ & 0.91 & 0.41 \\
\hline How often do you feel that life is full of opportunities? & $0.29 * * *$ & 0.87 & 0.51 \\
\hline $\begin{array}{c}\text { How often do you feel that the future looks good for you? } \\
\text { How often do you feel satisfied with activities }\end{array}$ & $0.34^{* * *}$ & 0.88 & 0.42 \\
\hline $\begin{array}{l}\text { (volunteering, hobbies } \\
\text { etc ...)? }\end{array}$ & $-0.14^{* * *}$ & 0.94 & 0.84 \\
\hline Total & & 0.87 & \\
\hline
\end{tabular}

Note: ${ }^{* * *} p<0.001$.

In the regression models of perceived health (Table 3), significant variables $(p<0.001)$ were 'How often your age prevents you from doing the things you would like to do?' $(\beta$ men, women $=-0.18)$, and 'How often do you feel/think full of energy these days?' $(\beta$ men $=0.30, \beta$ women $=-0.04)$. This model explained the $24.66 \%$ variance for men and $28.66 \%$ variance for women. In the case of women, the retained variables were 'How often do you feel/think that you can do the things that you want to do?' $(\beta=0.06)$. In men, there was a high coincidence for (with $p<0.001$ ) 'How often do you feel/think look back on your life with a sense of happiness?' ( $\beta=-0.13)$, and $p<0.01$ for the variable 'How often do you feel/think that family responsibilities prevent you from doing what you want to do?' $(\beta=0.09)$. The model obtained a slightly better fit for women $(\mathrm{F}, 13,771=28.66$ and $\mathrm{R} 2=0.33)$ than men $(\mathrm{F}, 13,781=24.66$ and $\mathrm{R} 2=0.29)$. 
Table 3. Linear standardized regression models of perceived health status by gender using SHARE data. Standardized $\beta$ coefficients.

\begin{tabular}{|c|c|c|c|c|}
\hline \multirow[t]{2}{*}{ Variables } & \multicolumn{2}{|c|}{$\begin{array}{l}\text { Men } \\
(N=1563)\end{array}$} & \multicolumn{2}{|c|}{$\begin{array}{l}\text { Women } \\
(N=1826)\end{array}$} \\
\hline & B & SE & B & SE \\
\hline $\begin{array}{c}\text { How often do you think your age prevents you from doing } \\
\text { the things you would like to do? }\end{array}$ & -0.18 & $0.03 * * *$ & -0.18 & $0.03^{* * *}$ \\
\hline $\begin{array}{c}\text { How often do you feel that what happens to you is out of } \\
\text { your control? }\end{array}$ & -0.06 & 0.04 & -0.06 & 0.04 \\
\hline How often do you feel left out of things?? & 0.03 & 0.04 & 0.03 & 0.04 \\
\hline $\begin{array}{l}\text { How often do you think that you can do the things that you } \\
\text { want to do? }\end{array}$ & 0.03 & 0.03 & 0.06 & $0.03 *$ \\
\hline $\begin{array}{c}\text { How often do you think that family responsibilities prevent } \\
\text { you from doing what you want to do? }\end{array}$ & 0.09 & $0.03 *$ & 0.04 & 0.03 \\
\hline $\begin{array}{l}\text { How often do you think that shortage of money stops you } \\
\text { from doing the things you want to do? }\end{array}$ & -0.06 & 0.03 & -0.06 & 0.03 \\
\hline How often do you look forward to each day? & 0.11 & 0.05 & 0.04 & 0.05 \\
\hline How often do you feel that your life has meaning? & 0.09 & 0.06 & 0.04 & 0.05 \\
\hline $\begin{array}{c}\text { How often, on balance, do you look back on your life with a } \\
\text { sense of happiness? }\end{array}$ & -0.13 & $0.04^{* * *}$ & -0.07 & 0.04 \\
\hline How often do you feel full of energy these days? & 0.30 & $0.05^{* * *}$ & 0.33 & $0.04^{* * *}$ \\
\hline How often do you feel that life is full of opportunities? & 0.08 & 0.05 & 0.04 & 0.04 \\
\hline How often do you feel that the future looks good for you? & 0.02 & 0.04 & 0.00 & 0.05 \\
\hline $\begin{array}{l}\text { How often do you feel satisfied with activities (volunteering, } \\
\text { hobbies etc ... )? }\end{array}$ & -0.02 & 0.02 & $-0,01$ & 0.02 \\
\hline \multirow[t]{3}{*}{ Constant } & $\begin{array}{c}2.81 \\
F(13,781)\end{array}$ & $\begin{array}{l}0.29 * * * \\
24.66\end{array}$ & $\begin{array}{c}3.07 \\
\mathrm{~F}(13,771)\end{array}$ & $\begin{array}{l}0.27^{* * *} \\
28.66\end{array}$ \\
\hline & Adj R-squared & $\begin{array}{c}24.00 \\
0.29\end{array}$ & Adj R-squared & 0.33 \\
\hline & Root MSE & 0.81 & Root MSE & 0.78 \\
\hline
\end{tabular}

Note: ${ }^{*} p<0.01 ;{ }^{* * *} p<0.001$; Prob $>\mathrm{F}=0.00$ for both models. SE $=$ Standard Error.

\section{Discussion}

This study responded to the question of how older Spanish people perceived their health, and compared their perceptions based on their sex. The main results are centred on the responses to statements such as 'How often do you feel/think full of energy these days?' and 'How often your age prevents you from doing the things you would like to do?' for both genders. In the case of women, it is remarkable the response to the statement 'How often do you feel/think that you can do the things that you want to do?'. In men, the statements 'How often do you feel/think look back on your life with a sense of happiness?' and 'How often do you feel/think that family responsibilities prevent you from doing what you want to do?' garnered more positive responses.

First, the results of this analysis showed how health is related to a negative assessment of activities; that is, health perception is linked more to agreement with negative ideas such as 'How often your age prevents you from doing the things you would like to do?' than to agreement with the positive idea that 'How often do you feel/think full of energy these days?'. In other words, people who say that age stops them from doing things perceive themselves as having poorer health, while people who consider that age gives them energy see themselves as enjoying better health.

Second, ageing is associated with increased musculoskeletal- or mobility-related diseases or problems, which is consistent with previous studies [54-56]. This study shows that $60.4 \%$ of the participants were limited in activities as a result of mobility difficulties or chronic diseases.

Third, the results displayed a lower association of perceived health with statements such as 'How often do you feel that your life has meaning?' and 'How often do you feel satisfied with activities (volunteering, hobbies etc ... )?', particularly in women. In addition, because women generally have more family and care commitments than men 
when they are younger, they may find that having more time for other activities as they become older makes them feel more enthusiastic and positive; unfortunately, they may also find that they do not have as much vitality as they would like at this life stage, because of the previously mentioned physical changes they experience.

All of these data also justify the need for person-centred studies, i.e., ergonomic and usability studies for products designed to increase mobility with the goal of fostering greater independence. Moreover, the use of technology in health, relational and psychosocial support devices for older people highlights the need for further research on the applicability and use of systems that improve their effectiveness and ergonomics. This is much more relevant for specific socio-demographic profiles, such as women living in rural areas or in less accessible areas with fewer services, but who also have positive experiences at the relational level $[18,56]$.

Another aspect to consider is that ageing being connected to fewer family responsibilities is perceived more positively in relation to health by men than by women, which is undoubtedly linked to the ongoing care provided by women, who continue to look after family members and dependents even as they themselves age [18]. In addition, it is worth remembering the increase in dependent ageing in rural areas also increases the need of care and social resources, due to the increase in recent years of dependent persons who are over 65 years old. It is estimated that, in the coming years, this problem will most likely grow, giving rise to new group profiles of older people who are at risk of being dependent persons, especially in the context of the current pandemic and as a direct result of having suffered from the virus $[57,58]$. In short, there are differences in terms of how life is perceived with greater family responsibilities and commitments when one is a woman, but women are also slightly more optimistic and have a more positive sense of purpose, or 'ikigai'.

Middle-aged and older people express greater concern about the general economic situation in Spain than they do about their own personal financial situation and future, as shown by their responses to the prompts 'Degree of concern about the situation' and 'The degree of optimism'. That is to say, there is a certain vitality and optimism that can be observed in older people which, together with the analysed perception of health, is related to their need to feel useful and valued in society [15]; this is especially observed in older women. Unfortunately, the current socio-political and economic context of the pandemic may trigger a negative perception of health and the future in groups that have experienced a high rate of vulnerability/mortality in connection with the virus; this will affect these senior citizens' quality of life, as they may see their future as more uncertain.

With regard to the limitations of this study, the first limitation is linked to the Likert scale variables used: all of the ageing perception variables are Likert data. The second limitation refers to the lack of more recent surveys or questionnaires due to the pandemic; such studies would be useful in updating the data reported in this study. Furthermore, qualitative studies might help to analyse the direct discourses of older people or of the carers, either in the homes or in different residential environments. A third limitation of this study is related to the current pandemic: COVID-19 has slowed down this successful process and is regarded as the most important public health disease of the last 100 years for the world's population; it is the main cause of hospitalization and death, particularly for older people, and has reduced life expectancy at all latitudes [59]. In particular, the high mortality rate due to illness and complications caused by the SARs-CoV-2 virus in the Spanish population is bringing about a negative change in future prospects, especially for men [60]. Furthermore, complications are even greater for those who suffer from heart disease, diabetes and/or chronic bronchitis [61-63]. In addition, people affected (directly or indirectly, for example, women and residential carers) by the new disease of COVID-19 may be more vulnerable to suffering certain motor pathologies as a consequence of the disease, for example, due to thrombosis in infected persons [64-66], necrosis [67] due to complications, such as avascular necrosis [68], along with other issues of a sensory nature. Unfortunately, however, in the current socio-political and economic context of the pandemic, a negative perception of health is emerging in groups with a high COVID-19 
mortality/vulnerability rate. Obviously, this new disease will affect not only their health, quality of life and the future (perceived and real) of adults and older people, but also that of their carers, who are still mostly women, whether they are family members or professional caregivers [18,69-72]. Moreover, the effects could have a negative impact on the continuity of care in dependency situations, which adds to the inequalities experienced by those living in rural areas. For example, rural disparities in accessibility impede mobility [73] and access to healthcare services, and they hinder continuity of care [74]. These barriers could have negative repercussions on the healthcare coverage of patients with diabetes and hypertension [75]. In this regard, there are some positive experiences with chronic disease management in rural areas where nurses intervene to provide more continuous care [76]. This type of program could be implemented in both social and healthcare resources in rural areas for patients with chronic diseases.

As far as the continuity of care goes, some of the great social and health solutions that have been implemented involve using technological resources, such as telemedicine $[77,78]$ and emerging technologies focused on improving the autonomy [72] of older people. These emerging technologies include design concepts, such as accessibility, usability, safety, ergonomics, people preferences and also gender perspectives [72,78]. In addition to providing greater continuity of care, these technologies can be used to reduce the problems of loneliness and isolation (which are often experienced by older people) [19].

Within the context of pandemic, it is still unclear if rural spaces are healthier environments, or if there may be less chance of being infected by the virus in these areas. The social perception of health is influenced by the belief that urban dwellers are at a higher risk of COVID-19 infection than people living in rural areas [79]. However, there are other health issues in rural areas. The limited access and difficulty reaching rural healthcare and support, poor Internet connectivity and the still-existing digital divide do carry other risks that affect those living outside urban areas: the inequities in healthcare for older people [80], the loneliness, isolation and other problems caused by social distancing [81].

Clearly, more research regarding the current perception of health in the context of the pandemic and different socio-spatial scenarios (including rural/urban areas) could be developed, particularly considering the positive impact of emerging technologies that will affect the future of older people and their caregivers.

Finally, this study is only centred on the gender perspective. Other analysis could be entered into new models (e.g., socio-economic status, health status, pain status, living with others vs. alone, mental health status) which are included in SHARE questionnaire.

\section{Conclusions}

Broadly speaking, older people's perceptions with regard to their health and future was negative before the COVID-19 pandemic, but there were glimpses of optimism in some responses to prompts regarding their personal situation. Above all, there are gender differences and, even though women have a longer life expectancy, the continuity and pressure of family care commitments continues to be high at this stage of life $(\leq 50)$ for the female population. This persistence of gender-based roles, among other explanations or variables, leads middle-aged and older women to perceive their health and quality of life more negatively, which also leads them to feel less vital and more dissatisfied with activities such as volunteering and hobbies. In sum, older women die later than their male peers, but this does not imply that their quality of life and perception of health is more positive or negative. Rural older women make a positive evaluation of their health and feel at their age more enthusiastic but less vital than they would like to be, while rural older men connect good health to passivity and reminiscence.

Consequently, there is a need for further research on psycho-social issues with regard to the impact of SARS-CoV-2 virus. Adopting a gender, socio-spatial, inclusive and intergenerational approach could be a key factor in better understanding health perception and targeting programmes/policies for better health and social sustainability, satisfaction and quality of life for older people in different regions. 


\begin{abstract}
Author Contributions: All the authors have equally contributed to the final version of this paper. All
\end{abstract} authors have read and agreed to the published version of the manuscript.

Funding: This work is part of the 'Quality of life and Ageing in Spain, Sweden and Portugal'. The QASP research project is funded by the Institute of Health Carlos III, Intramural Strategical Action in Health AESI 2018, Ref: PI18CIII/00046, PR: MR Forjaz. https:/ / qaspresearch.wixsite.com/blog (accessed on 20 November 2021). We appreciate the support of the 'Active Aging, Quality of Life and Gender. Promoting a positive image of old age and aging combating ageism' ProgramENCAGEn cm R\&D Activities Program. Ref. H2019/HUM-5698. Funded by Programs of R\&D in Community of Madrid Social Sciences and Humanities, co-financed with the European Social Fund.PR: G. Fernández-Mayoralas, C Rodriguez-Blazquez, D. Zamarrón, M.S. Agulló-Tomás, M.A. Molina. https: / / encage-cm.es / (accessed on 20 November 2021).

Institutional Review Board Statement: Not applicable.

Informed Consent Statement: Not applicable.

Data Availability Statement: As indicated, data used the Survey of Health, Ageing and Retirement, SHARE: http:/ / www.share-project.org/home0.html (accessed on 15 November 2021).

Conflicts of Interest: The authors declare no conflict of interest.

\title{
References
}

1. The World Bank Data. Population Ages 65 and Above (\% of Total Population). 2022. Available online: https://data.worldbank. org/indicator/SP.POP.65UP.TO.ZS (accessed on 21 November 2021).

2. WHO. Ageing and Health. 2021. Available online: https://www.who.int/news-room/fact-sheets/detail/ageing-and-health (accessed on 16 January 2022).

3. WHO. UN Decade of Healthy Ageing. 2021. Available online: https://www.who.int/initiatives/decade-of-healthy-ageing (accessed on 16 January 2022).

4. Gabriel, Z.; Bowling, A.N.N. Quality of life from the perspectives of older people. Ageing Soc. 2004, 24, 675-691. [CrossRef]

5. Bowling, A.; Fleissig, A.; Gabriel, Z.; Banister, D.; Dykes, J.; Dowding, L.M.; Sutton, S.; Evans, O. Let's ask them: A national survey of definitions of quality of life and its enhancement among people aged 65 and over. Int. J. Aging Hum. Dev. 2003, 56, 269-306. [CrossRef] [PubMed]

6. Connolly, S.; O'shea, E. The Perceived Benefits of Participating in Voluntary Activities Among Older People: Do They Differ by Volunteer Characteristics? Act. Adapt. Aging 2015, 39, 95-108. [CrossRef]

7. Havighurst, R.J. Successful aging. In Processes of Aging; Williams, R.H., Tibbits, C., Donahue, W., Eds.; Atherton Press: New York, NY, USA, 1963; Volume 1, pp. 299-320.

8. Spreitzer, E.; Snyder, E.E. Correlates of life satisfaction among the aged. J. Gerontol. 1974, 29, 454-458. [CrossRef] [PubMed]

9. Brandtstädter, J.; Baltes-Götz, B. Personal control over development and quality of life perspectives in adulthood. In Successful Aging: Perspectives from the Behavioral Sciences; Baltes, M.M., Baltes, P.B., Eds.; European Network on Longitudinal Studies on Individual Development; Cambridge University Press: Cambridge, UK, 1990; pp. 197-224.

10. WHO. Report of the Second World Assembly on Ageing; United Nations: New York, NY, USA, 2002.

11. Bowling, A. Ageing Well: Quality of Life in Old Age; Open University Press: Maidenhead, UK, 2005.

12. Walker, A. Understanding Quality of Life in Old Age; Open University Press: Maidenhead, UK, 2005.

13. Cattan, M.; Hogg, E.; Hardill, I. Improving quality of life in ageing populations: What can volunteering do? Maturitas 2011, 70, 328-332. [CrossRef] [PubMed]

14. Fernández-Mayoralas, G.; Rojo-Pérez, F.; Martínez-Martín, P.; Prieto-Flores, M.E.; Rodríguez-Blázquez, C.; Martín-García, S.; Rojo-Abuín, J.M.; Forjaz, M.J. Active ageing and quality of life: Factors associated with participation in leisure activities among institutionalized older adults, with and without dementia. Aging Ment. Health 2015, 19, 1031-1041. [CrossRef]

15. Zorrilla-Muñoz, V.; Blanco-Ruiz, M.; Criado-Quesada, B.; Fernandez-Sanchez, M.; Merchan-Molina, R.; Agulló-Tomás, M.S.A.; Género y envejecimiento desde el prisma de las organizaciones que trabajan con mayores. Rev. Prism. Soc. 2018, 500-510. Available online: https: / revistaprismasocial.es/article/view/2468 (accessed on 16 December 2021).

16. Agulló-Tomás, M.S.; Zorrilla-Muñoz, V.; Gómez-García, M.V. Aproximación socio-espacial al envejecimiento ya los programas para cuidadoras/es de mayores. Rev. INFAD Psicol. Int. J. Dev. Educ. Psychol. 2019, 2, 211-228. [CrossRef]

17. Chien, W.-T.; Chiu, Y.; Lam, L.-W.; Ip, W.-Y. Effects of a needs-based education programme for family carers with a relative in an intensive care unit: A quasi-experimental study. Int. J. Nurs. Stud. 2006, 43, 39-50. [CrossRef]

18. Agulló-Tomás, M.S.; Zorrila-Muñoz, V.; Gomez-Garcia, M.V.; Género y evaluación de programas de apoyo para cuidadoras/es de mayores. Prism. Soc. Rev. Investig. Soc. 2018, 391-415. Available online: https://revistaprismasocial.es/article/view/2469 (accessed on 16 December 2021).

19. Blusi, M.; Asplund, K.; Jong, M. Older family carers in rural areas: Experiences from using caregiver support services based on Information and Communication Technology (ICT). Eur. J. Ageing 2013, 10, 191-199. [CrossRef] 
20. Walker, A. The New Generational Contract: Intergenerational Relations, Old Age and Welfare; ULC Press: London, UK, 1996.

21. von Steinbüchel, N.; Lischetzke, T.; Gurny, M.; Eid, M. Assessing quality of life in older people: Psychometric properties of the WHOQOL-BREF. Eur. J. Ageing 2006, 3, 116-122. [CrossRef]

22. Lucas-Carrasco, R.; Laidlaw, K.; Power, M.J. Suitability of the WHOQOL-BREF and WHOQOL-OLD for Spanish older adults. Aging Ment. Health 2011, 15, 595-604. [CrossRef]

23. Prieto-Flores, M.-E.; Moreno-Jiménez, A.; Fernandez-Mayoralas, G.; Rojo-Perez, F.; Forjaz, M.J. The relative contribution of health status and quality of life domains in subjective health in old age. Soc. Indic. Res. 2012, 106, 27-39. [CrossRef]

24. Forjaz, M.J.; Rodriguez-Blazquez, C.; Ayala, A.; Rodriguez-Rodriguez, V.; de Pedro-Cuesta, J.; Garcia-Gutierrez, S.; Prados-Torres, A. Chronic conditions, disability, and quality of life in older adults with multimorbidity in Spain. Eur. J. Intern. Med. 2015, 26, 176-181. [CrossRef] [PubMed]

25. Santos Alexandre, R. Being and landscape: An ontological inquiry into a Japanese rural community. Asia Pac. J. Anthropol. 2019, 20, 232-246. [CrossRef]

26. Foreman, K.J.; Marquez, N.; Dolgert, A.; Fukutaki, K.; Fullman, N.; McGaughey, M.; Pletcher, M.A.; Smith, A.E.; Tang, K.; Yuan, C.-W. Forecasting life expectancy, years of life lost, and all-cause and cause-specific mortality for 250 causes of death: Reference and alternative scenarios for 2016-40 for 195 countries and territories. Lancet 2018, 392, 2052-2090. [CrossRef]

27. Wenger, G.C. Myths and realities of ageing in rural Britain. Ageing Soc. 2001, 21, 117-130. [CrossRef]

28. Banjare, P.; Dwivedi, R.; Pradhan, J. Factors associated with the life satisfaction amongst the rural elderly in Odisha, India. Health Qual. Life Outcomes 2015, 13, 201. [CrossRef] [PubMed]

29. Kim, H.J. Health promotion behaviors of rural elderly women living alone and their life satisfaction. J. Korean Acad. Community Health Nurs. 2016, 27, 254-261. [CrossRef]

30. Giang, L.T.; Nguyen, T.T.; Nguyen, N.T. Social support and self-rated health among older men and women in Vietnam. J. Popul. Ageing 2020, 13, 427-442. [CrossRef]

31. Dassah, E.; Aldersey, H.; McColl, M.A.; Davison, C. Factors affecting access to primary health care services for persons with disabilities in rural areas: A “best-fit” framework synthesis. Glob. Health Res. Policy 2018, 3, 1-13. [CrossRef]

32. Pino, L.; González-Vélez, A.E.; Prieto-Flores, M.E.; Ayala, A.; Fernandez-Mayoralas, G.; Rojo-Perez, F.; Martinez-Martin, P.; Forjaz, M.J. Self-perceived health and quality of life by activity status in community-dwelling older adults. Geriatr. Gerontol. Int. 2014, 14, 464-473. [CrossRef] [PubMed]

33. Ingrand, I.; Paccalin, M.; Liuu, E.; Gil, R.; Ingrand, P. Positive perception of aging is a key predictor of quality-of-life in aging people. PLoS ONE 2018, 13, e0204044. [CrossRef] [PubMed]

34. Sexton, E.; King-Kallimanis, B.L.; Morgan, K.; McGee, H. Development of the Brief Ageing Perceptions Questionnaire (B-APQ): A confirmatory factor analysis approach to item reduction. BMC Geriatr. 2014, 14, 44. [CrossRef] [PubMed]

35. Yaghoobzadeh, A.; Sharif Nia, H.; Hosseinigolafshani, Z.; Mohammadi, F.; Oveisi, S.; Torkmandi, H. Associated factors of ageing perception among elderly in Qazvin, 2015. J. Gerontol. 2017, 1, 1-10. [CrossRef]

36. Santini, Z.I.; Koyanagi, A.; Tyrovolas, S.; Haro, J.M.; Koushede, V. The association of social support networks and loneliness with negative perceptions of ageing: Evidence from the Irish Longitudinal Study on Ageing (TILDA). Ageing Soc. 2019, 39, 1070-1090. [CrossRef]

37. Mohammadpour, A.; Sadeghmoghadam, L.; Shareinia, H.; Jahani, S.; Amiri, F. Investigating the role of perception of aging and associated factors in death anxiety among the elderly. Clin. Interv. Aging 2018, 13, 405. [CrossRef] [PubMed]

38. Warmoth, K.; Tarrant, M.; Abraham, C.; Lang, I.A. Relationship between perceptions of ageing and frailty in English older adults. Psychol. Health Med. 2018, 23, 465-474. [CrossRef]

39. Freeman, A.T.; Santini, Z.I.; Tyrovolas, S.; Rummel-Kluge, C.; Haro, J.M.; Koyanagi, A. Negative perceptions of ageing predict the onset and persistence of depression and anxiety: Findings from a prospective analysis of the Irish Longitudinal Study on Ageing (TILDA). J. Affect. Disord. 2016, 199, 132-138. [CrossRef]

40. Warmoth, K.; Tarrant, M.; Abraham, C.; Lang, I.A. Older adults' perceptions of ageing and their health and functioning: A systematic review of observational studies. Psychol. Health Med. 2016, 21, 531-550. [CrossRef] [PubMed]

41. Hickey, A.; O'Hanlon, A.; McGee, H. Quality of life in community-dwelling older people in Ireland: Association with ageing perceptions, physical health and psychological well-being. Ir. J. Psychol. 2010, 31, 135-150. Available online: http://salmandj. uswr.ac.ir/article-1-1011-en.html (accessed on 17 December 2021). [CrossRef]

42. Sadegh Moghadam, L.; Foroughan, M.; Mohammadi, F.; Ahmadi, F.; Farhadi, A.; Nazari, S.; Sadeghi, N. Aging perception in older adults. Iran. J. Ageing 2016, 10, 202-209. Available online: http:/ / salmandj.uswr.ac.ir/article-1-1011-en.html (accessed on 17 December 2021).

43. Slotman, A.; Cramm, J.M.; Nieboer, A.P. Validation of the Dutch Aging Perceptions Questionnaire and development of a short version. Health Qual. Life Outcomes 2015, 13, 54. [CrossRef] [PubMed]

44. Jaafar, M.H.; Villiers-Tuthill, A.; Sim, S.H.; Lim, M.A.; Morgan, K. Validation of the brief ageing perceptions questionnaire (B-APQ) in Malaysia. Aging Ment. Health 2020, 24, 620-626. Available online: http://www.share-project.org/uploads/tx_ sharepublications /201804_SHARE-WAVE-6_MFRB.pdf (accessed on 15 November 2021). [CrossRef] [PubMed]

45. Malter, F.; Börsch-Supan, A. SHARE Wave 6: Panel Innovations and Collecting Dried Blood Spots; MEA, Max Planck Institute for Social Law and Social Policy: Munich, Germany, 2017; Available online: http://www.share-project.org/uploads/tx_sharepublications/ 201804_SHARE-WAVE-6_MFRB.pdf (accessed on 15 November 2021). 
46. SHARE. SHARE Conditions of Use. 2022. Available online: http://www.share-project.org/data-access/share-conditions-of-use. html (accessed on 10 January 2022).

47. Bergmann, M.; Kneip, T.; De Luca, G.; Scherpenzeel, A. Survey Participation in the Survey of Health, Ageing and Retirement in Europe (SHARE), Wave 1-6; Working Paper Series 41-2019; Munich Center for the Economics of Aging: Munich, Germany, 2019; Available online: http://www.share-project.org/uploads/tx_sharepublications/WP_Series_41_2019_Bergmann_et_al.pdf (accessed on 15 December 2021).

48. Börsch-Supan, A. Survey of Health, Ageing and Retirement in Europe (SHARE) Wave 6; Release Version: 7.0.0; SHARE-ERIC, Munich Center for the Economics of Aging (MEA): Munich, Germany, 2019; Available online: http://www.share-project.org/datadocumentation/waves-overview/wave-6.html (accessed on 15 November 2021).

49. López Zubizarreta, M.; Hernández Mezquita, M.Á.; Miralles García, J.M.; Barrueco Ferrero, M. Tobacco and diabetes: Clinical relevance and approach to smoking cessation in diabetic smokers. Endocrinol. Diabetes Nutr. 2017, 64, 221-231. [CrossRef] [PubMed]

50. Gritz, E.R.; Vidrine, D.J.; Fingeret, M.C. Smoking cessation: A critical component of medical management in chronic disease populations. Am. J. Prev. Med. 2007, 33, S414-S422. [CrossRef] [PubMed]

51. Wiggins, R.D.; Netuveli, G.; Hyde, M.; Higgs, P.; Blane, D. The evaluation of a self-enumerated scale of quality of life (CASP-19) in the context of research on ageing: A combination of exploratory and confirmatory approaches. Soc. Indic. Res. 2008, 89, 61-77. [CrossRef] [PubMed]

52. Rodríguez-Blázquez, C.; Ribeiro, O.; Ayala, A.; Teixeira, L.; Araújo, L.; Forjaz, M.J. Psychometric properties of the CASP-12 scale in Portugal: An analysis using SHARE data. Int. J. Environ. Res. Public Health 2020, 17, 6610. [CrossRef] [PubMed]

53. Von dem Knesebeck, O.; Hyde, M.; Higgs, P.; Kupfer, A.; Siegriest, J. Quality of life and wellbeing. In Health, Ageing and Retirement in Europe: First Results from the Survey of Health, Ageing and Retirement in Europe; Borsch-Supan, A., Nrugiavini, A., Jurges, H., Mackenbach, J., Siegriest, J., Weber, G., Eds.; MEA: Mannheim, Germany, 2005; pp. 199-203.

54. Cimas, M.; Ayala, A.; Sanz, B.; Agulló-Tomás, M.S.; Escobar, A.; Forjaz, M.J. Chronic musculoskeletal pain in European older adults: Cross-national and gender differences. Eur. J. Pain 2018, 22, 333-345. [CrossRef] [PubMed]

55. Metz, D.H. Mobility of older people and their quality of life. Transp. Policy 2000, 7, 149-152. [CrossRef]

56. Zorrilla-Muñoz, V.; Agulló-Tomás, M.S.; Garcia-Sedano, T. Análisis socio-ergonómico en la agricultura. Evaluación del sector oleico desde una perspectiva de género y envejecimiento. ITEA Inf. Técnica Económica Agrar. Rev. Asoc. Interprofesional Para El Desarro. Agrar. (AIDA) 2019, 115, 83-104. [CrossRef]

57. Mitrani, R.D.; Dabas, N.; Goldberger, J.J. COVID-19 cardiac injury: Implications for long-term surveillance and outcomes in survivors. Heart Rhythm 2020, 17, 1984-1990. [CrossRef] [PubMed]

58. Paliwal, V.K.; Garg, R.K.; Gupta, A.; Tejan, N. Neuromuscular presentations in patients with COVID-19. Neurol. Sci. 2020, 41, 3039-3056. [CrossRef] [PubMed]

59. Marois, G.; Muttarak, R.; Scherbov, S. Assessing the potential impact of COVID-19 on life expectancy. PLoS ONE 2020, 15, e0238678. [CrossRef] [PubMed]

60. Ruiz-Cantero, M.T. Las estadísticas sanitarias y la invisibilidad por sexo y de género durante la epidemia de COVID-19. Gac. Sanit. 2021, 35, 95-98. [CrossRef] [PubMed]

61. Chudasama, Y.V.; Gillies, C.L.; Zaccardi, F.; Coles, B.; Davies, M.J.; Seidu, S.; Khunti, K. Impact of COVID-19 on routine care for chronic diseases: A global survey of views from healthcare professionals. Diabetes Metab. Syndr. Clin. Res. Rev. 2020, 14,965-967. [CrossRef] [PubMed]

62. Jordan, R.E.; Adab, P.; Cheng, K. COVID-19: Risk factors for severe disease and death. BMJ 2020, 368, m1198. [CrossRef]

63. Schett, G.; Sticherling, M.; Neurath, M.F. COVID-19: Risk for cytokine targeting in chronic inflammatory diseases? Nat. Rev. Immunol. 2020, 20, 271-272. [CrossRef] [PubMed]

64. Connors, J.M.; Levy, J.H. COVID-19 and its implications for thrombosis and anticoagulation. Blood 2020, 135, 2033-2040. [CrossRef] [PubMed]

65. Hashemi, A.; Madhavan, M.V.; Bikdeli, B. Pharmacotherapy for Prevention and Management of Thrombosis in COVID-19. Semin. Thromb. Hemost. 2020, 46, 789-795. [CrossRef] [PubMed]

66. McFadyen, J.D.; Stevens, H.; Peter, K. The Emerging Threat of (Micro)Thrombosis in COVID-19 and Its Therapeutic Implications. Circ. Res. 2020, 127, 571-587. [CrossRef] [PubMed]

67. Feldmann, M.; Maini, R.N.; Woody, J.N.; Holgate, S.T.; Winter, G.; Rowland, M.; Richards, D.; Hussell, T. Trials of anti-tumour necrosis factor therapy for COVID-19 are urgently needed. Lancet 2020, 395, 1407-1409. [CrossRef] [PubMed]

68. Agarwala, S.R.; Vijayvargiya, M.; Pandey, P. Avascular necrosis as a part of 'long COVID-19'. BMJ Case Rep. CP 2021, 14, e242101. [CrossRef] [PubMed]

69. Campbell, S.M.; Roland, M.O.; Buetow, S.A. Defining quality of care. Soc. Sci. Med. 2000, 51, 1611-1625. [CrossRef] [PubMed]

70. Di Rosa, M.; Kofahl, C.; McKee, K.; Bień, B.; Lamura, G.; Prouskas, C.; Döhner, H.; Mnich, E. A typology of caregiving situations and service use in family carers of older people in six European countries. GeroPsych 2011, 24, 5-18. [CrossRef]

71. Agulló-Tomás, M.S.; Zorrilla-Muñoz, V. Technologies and Images of Older Women. In Human Aspects of IT for the Aged Population. Technology and Society. HCII 2020. Lecture Notes in Computer Science 12209; Gao, Q., Zhou, J., Eds.; Springer: Cham, Switzerland, 2020; pp. 163-175. [CrossRef] 
72. Zorrilla-Muñoz, V.; Agulló-Tomás, M.S.; Forjaz, M.J.; Fernandez, E.; Rodriguez-Blazquez, C.; Ayala, A.; Fernandez-Mayoralas, G. Technology, Gender and COVID-19. Analysis of Perceived Health in Adults and Older People. In Human Aspects of IT for the Aged Population. Supporting Everyday Life Activities. HCII 2021. Lecture Notes in Computer Science; Gao, Q., Zhou, J., Eds.; Springer: Cham, Switzerland, 2021; pp. 363-379. [CrossRef]

73. Camarero, L.; Oliva, J. Thinking in rural gap: Mobility and social inequalities. Palgrave Commun. 2019, 5, 95. [CrossRef]

74. Apostolopoulos, N.; Ratten, V.; Stavroyiannis, S.; Makris, I.; Apostolopoulos, S.; Liargovas, P. Rural health enterprises in the EU context: A systematic literature review and research agenda. J. Enterprising Communities People Places Glob. Econ. 2020, 14, 4, 563-582. [CrossRef]

75. Carrillo-Balam, G.; Cantoral, A.; Rodríguez-Carmona, Y.; Christensen, D.L. Health-care coverage and access to health care in the context of type 2 diabetes and hypertension in rural Mexico: A systematic literature review. Public Health 2020, 181, 8-15. [CrossRef] [PubMed]

76. Davisson, E.A.; Swanson, E.A. Patient and Nurse Experiences in a Rural Chronic Disease Management Program. Prof. Case Manag. 2018, 23, 10-18. [CrossRef] [PubMed]

77. Miele, G.; Straccia, G.; Moccia, M.; Leocani, L.; Tedeschi, G.; Bonavita, S.; Lavorgna, L.; Digital Technologies Web; Social Media Study Group of the Italian Society of Neurology. Telemedicine in Parkinson's disease: How to ensure patient needs and continuity of care at the time of COVID-19 pandemic. Telemed. e-Health 2020, 26, 1533-1536. [CrossRef] [PubMed]

78. Criado-Quesada, B.; Zorrilla-Muñoz, V.; Agulló-Tomás, M.S. El uso de tecnologías de asistencia sanitaria digital por parte de la población mayor desde una perspectiva de género e intrageneracional. Teknokultura 2021, 18, 103-113. [CrossRef]

79. Chisty, M.A.; Islam, M.A.; Munia, A.T.; Rahman, M.M.; Rahman, N.N.; Mohima, M. Risk perception and information-seeking behavior during emergency: An exploratory study on COVID-19 pandemic in Bangladesh. Int. J. Disaster Risk Reduct. 2021, 65, 102580. [CrossRef] [PubMed]

80. Henning-Smith, C. The unique impact of COVID-19 on older adults in rural areas. J. Aging Soc. Policy 2020, 32, 396-402. [CrossRef] [PubMed]

81. Fuller, H.R.; Huseth-Zosel, A. Older adults' loneliness in early COVID-19 social distancing: Implications of rurality. J. Gerontol. Ser. B Psychol. Sci. Soc. Sci. 2021, gbab053. [CrossRef] [PubMed] 